\title{
DEBIUTY
}

Agnieszka Przywara

Rzeszów

\section{Filigrany na kartach starodruków z biblioteki Wyższego Seminarium Duchownego w Rzeszowie ${ }^{1}$}

Jedną $z$ bibliotek funkcjonujących się na terenie Rzeszowa jest Biblioteka Wyższego Seminarium Duchownego. Powstała w 1993 roku w momencie erygowania seminarium. Główny zrąb pierwotnego księgozbioru stworzono na bazie darów licznych osób duchownych i świeckich, jak również instytucji oraz pokrewnych uczelni $z$ ościennych diecezji. Gromadzenie zbiorów jest ukierunkowane przede wszystkim na literaturę teologiczno-filozoficzną, zgodna $z$ profilem kształcenia WSD. Jednakże w księgozbiorze znajdują się również ksiażki o innym charakterze; i chociaż odbiegają one swą tematyką od profilu podstawowego, to jednocześnie podnoszą rangę książnicy. Biblioteka, która ma w swych zbiorach stare druki jest szczególnie nobilitowana. Rzeszowska książnica seminaryjna posiada wprawdzie niewielki zbiór książek starodrucznych, lecz bardzo cennych ze względu na warsztat, w którym je wytworzono.

Kolekcja ta liczy obecnie 29 starych druków ${ }^{2}$. Wszystkie trafiły do tutejszej placówki w drodze darów od nieustalonych w większości przypadków osób. Wyjątek stanowi egzemplarz pt. Joseph somnians complectens falsas variorum imaginationes autorstwa Joannesa $z$ Heumen ${ }^{3}$, który zostal podarowany tutejszej bibliotece przez ks. dra Sławomira Zycha. Trzy ostatnio dołączone woluminy zostały przekazane przez ks. Boguslawa Bogaczewicza, proboszcza parafii we Frysztaku. Początkowo książki te przechowywane były w magazynie głównym. Od trzech lat zabezpieczono je w oddzielnej zamykanej szafie. Szersze zainteresowanie omawianym zbiorem przez piszącą tę pracę pozwoliło na odkrycie wielu ciekawych aspektów związanych $z$ badanymi woluminami. Liczne zapiski mar-

\footnotetext{
${ }^{1}$ Artykul jest fragmentem pracy magisterskiej napisanej pod kierunkiem dr hab. Anny Kamler w Instytucie Informacji Naukowej i Studiów Bibliologicznych Uniwersytetu Warszawskiego.

${ }^{2}$ Opisywane filigrany pochodzą z 26 książek. Trzy pozostałe trafiły do Biblioteki już po złożeniu artykułu do druku. Są to: Ioanne de Carthagena, Homilie catholicae od Sacris arcanis deiparae Mariae et Iosephi, Coloniae Agrippinae, apud Ioannem Kinchium, 1641; T. Mangeart, Octave de sermons pour les morts, t. 1, Nancy, chez Leseure, 1739; Zbiór kazań w języku polskim wydany po roku 1766. Brak strony tytułowej i zły stan techniczny książi uniemożliwily podanie dokładnego opisu bibliograficznego ostatniego z wymienionych starych druków.

${ }^{3}$ Antwerpiae, pro Gerardo Sickens, approbat. 1660.
} 
ginalne a także różne dedykacje i pieczęcie pozwalają na przypuszczenia, co do pierwotnych wlaścicieli opisywanych ksiąg, ich zainteresowań a nawet myśli, które nasunęły się owemu czytelnikowi w danej chwili i pozostawiły swój ślad w postaci notatek i glos. Najstarsza książka pochodzi z roku 1596, najmłodsza z 1800. Najwięcej prezentowanych tu woluminów zostało wydanych w XVII i XVIII wieku. Przeważają druki w języku lacińskim. Pozostale to teksty francuskie, niemieckie i polskie. Najczęściej występującym miejscem wydania są tereny Cesarstwa Niemieckiego. Po trzy ksiażki powstało w Polsce i we Francji, natomiast pojedyncze w Holandii i Szwajcarii.

Dobrze zachowany znak wodny pozwala niejednokrotnie na ustalenie $z$ jakiej czerpalni pochodzil papier, na którym wytłoczono dane dzieło. Po raz pierwszy taki znak pojawil się we wloskiej papierni $z$ Fabriano w roku 1280. Początkowo kształty filigranów nie były zbytnio skomplikowane. Najczęściej przyjmowały formę krzyża, koła, owalu czy gwiazdy. Często dużą rolę odgrywały symbole religijne. $Z$ czasem znaki wodne zaczęły odzwierciedlać kształty bardziej skomplikowane. Wiele form zaczerpniętych zostało z życia codziennego oraz z przedmiotów, którymi papiernik otaczal się na co dzień. Stąd też filigrany przedstawiające narzędzia, części ubioru, przedmioty związane $z$ gospodarstwem domowym a także dotyczące samej papierni np. takie jak: koło wodne, waga, prasa itp. Coraz częściej pojawiają się znaki związane z kultem religijnym [pastorał, monstrancja], a także z życiem dworskim [korona, berło]. Pomysłów dostarczał też osprzęt rycerski [kusza, helm, strzała, miecz]. Niekiedy ksztalt filigranu zwiazany był $z$ miejscem czy regionem, $w$ jakim znajdowala się papiernia, np. w okolicach nadmorskich mógł to być kompas, statek czy kotwica. Bardzo często znaki wodne przyjmowały ksztalty zwierząt nie tylko znanych papiernikowi, ale i egzotycznych [słoń, lew]. Również nieograniczona fantazja rzemieślnika podsuwała mu pomysły na formę filigranu. Stąd nie trudno wśród zachowanych znaków wodnych odnaleźć różnego rodzaju smoki, syreny. jednorożce, gryfy itp. $Z$ czasem coraz powszechniejsze staje się wykorzystywanie jako filigranu herbów rycerskich czy miejskich ${ }^{4}$. Bardzo szybko tematyka filigranów przestala być przypadkowa. Znaki wodne przede wszystkim wskazywały na warsztat, $z$ którego pochodzil dany papier. W Europie Środkowej znak wodny najczęściej przedstawial herb właściciela gruntu, na którym znajdowal się młyn papierniczy oraz wlaśnie świadczyl o pochodzeniu arkusza papieru. Herb właściciela to przeważnie herb rycerski lub miejski i taki znak wodny stał się dominujący również w polskich papierniach ${ }^{5}$.

Znaki wodne odnajdywane na starym papierze od dawna budziły zainteresowanie. Pierwsze wzmianki, dotyczące jednakże bardziej kolekcjonerstwa niż naukowego podejścia badawczego, sięgają XVI wieku; nasilają się zwłaszcza na przelomie wieku XVIII i XIX. W efekcie poszukiwania te doprowadzily do powstania odrębnej dyscypliny badawczej, filigranistyki, która zaliczana jest do nauk pomocniczych historii ${ }^{6}$.

\footnotetext{
${ }^{4}$ K. Maleczyńska, Daieje starego papieru, Wrocław 1974, s. 130-133.

${ }^{5}$ Tamże, s. 134.

${ }^{6}$ J. Szymański, Nauki pomocnicze historii, wyd. 6, Warszawa 2006, s. 311.
} 
Z biegiem czasu zaczęły powstawać katalogi filigranów. Większość takich wydawnictw sporządzana jest $\mathrm{w}$ oparciu o przerysy ręczne prezentowanych znaków wodnych. Jednym $z$ pierwszych takich zestawień był album wydany $w$ roku 1899 przez rosyjskiego uczonego N. P. Lichaczewa. W swoim dziele zawarł znaki wodne odnalezione na papierach przechowywanych na terenie Rosji. Filigrany przedstawione $\mathrm{w}$ tym katalogu pochodzą $\mathrm{w}$ dużej mierze $\mathrm{z}$ papierów importowanych do Rosji, między innymi i $z$ polskich czerpalni. Prawie $w$ tym samym czasie powstał katalog znaków wodnych utworzony przez szwajcarskiego handlowca Karola Mojżesza Briqueta. W swojej wieloletniej pracy zgromadzil 44000 przerysów filigranów, zebranych $z$ dokumentów przechowywanych w wielu europejskich archiwach i bibliotekach. $Z$ tego potężnego zbioru wybrano 16000 . Na tej bazie powstało monumentalne dzieło, wydane w czterech tomach w Genewie pt. Les filigranes. Jednakże $z$ czasem okazało się, że wydanie drukiem wszystkich odnalezionych filigranów europejskich jest rzeczą niemożliwą. Dlatego stale tworzy się zbiory znaków wodnych, które nie były publikowane drukiem. Takie duże zestawienie $w$ okresie międzywojennym sporządzil m.in. uczony niemiecki Karol Teodor Weiss. Po wojnie znacznie poszerzyl je jego syn, Wisso Weiss. Katalog Weissów liczy 173000 oryginałów oraz 42000 przerysów. Także bardzo wartościową kolekcje stworzyl Alfred Schulte, który zgromadzil 160000 oryginalnych filigranów ${ }^{7}$. Wielkim dziełem jest także wielotomowa praca Gerharda Piccarda, w którym udokumentował około 120000 kart ze znakami wodnymi ${ }^{8}$.

Biblioteka WSD w Rzeszowie posiada, jak już wspomniano, niewielki zbiór książek starodrucznych. Jednakże, można je zaliczyć do bardzo interesujących ze względu na unikatowe zapisy proweniencyjne czy piękne oprawy. Prezentowane poniżej odbicia filigranów $w$ wielu przypadkach nie zostały odnalezione w materiale porównawczym, co pozwala wysnuć wniosek, że być może są tu prezentowane po raz pierwszy.

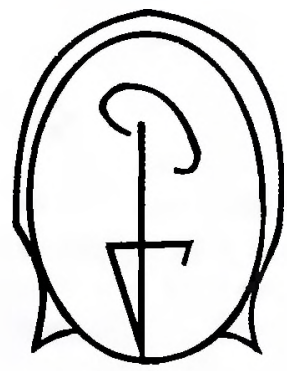

Rys. 1

${ }^{7}$ K. Maleczyniska, dz. cyt, s. 165-169.

${ }^{8}$ Dzięki powstalemu w archiwum stuttgarckim projektowi dzielo Piccarda dostępne jest także w wersji elektronicznej. Forma ta pozwoliła również na udostępnienie wszystkich filigranów zgromadzonych przez G. Piccarda, bowiem wydanie tradycyjne nie zamieszczalo wielu znaków ze względu na zły stan zachowanych materiałów. Zob. Hauptstaatsarchiv Stuttgart [online]: http://www.piccard-online.de/start. php [dostęp 3 listopada 2009]. 
Filigran ten (rys.1), występuje w dwóch tytułach: Mądrości Syracha, czyli Ekle$z j a s t y k$ w interpretacji Johannesa Drusiusa oraz w komentarzu do tej księgi biblijnej tego samego autora ${ }^{9}$. Oba dzieła zostały wydane w roku 1596. Pierwsze $z$ wymienionych dziel wydrukowano w Holandii w miejscowości Franeker. $\mathrm{W}$ drugim, na stronie tytułowej nie podano miejsca wydania. Jednakże skoro do druku użyto papieru $z$ tej samej papierni (świadczą o tym powtarzajace się znaki wodne), można mniemać, iż również komentarz został wydany w tym samym miejscu.

Prezentowany filigran jest jednym $z$ wielu odnalezionych na kartach tych dwóch dzieł. Przedstawiony znak może być zaczerpnięty $z$ runicznego alfabetu germańskiego. Po odwróceniu symbolu otrzyma się runę PARD. Oznacza ona konia a także boga wojny Wotana ${ }^{10}$. Ogólnie wiadomo, że według wierzeń $z$ runami wiąże się rodzaj magii. Być może wytwórca papieru, na którym pojawil się taki filigran wierzył w jakąś moc, która miała mu przynieść zyski związane $\mathrm{z}$ produkcją i zbytem wytwarzanego papieru.

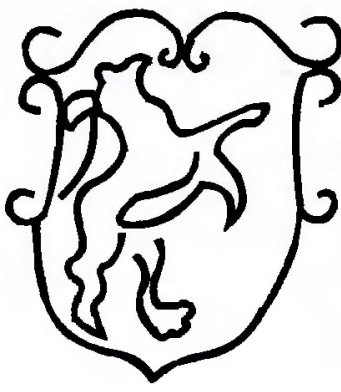

Rys. 2

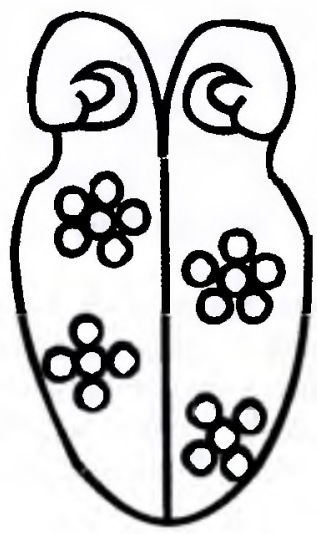

Rys. 3

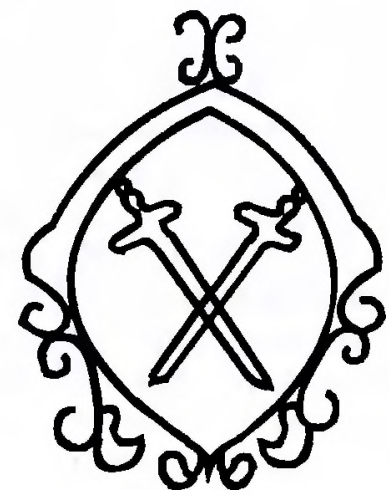

Rys. 4

Trzy kolejne filigrany (rys. 2, 3, 4) zostały odbite, tak jak poprzedni znak wodny, $z$ wyżej wymienionych dzieł Johannesa Drusiusa wydanych w roku 1596 w Holandii. Papiernictwo holenderskie rozwinęło się na szerszą skalę po roku 1592. Wcześniej istniały nieliczne młyny papiernicze, $z$ czego udokumentowana jest działalność czerpalni z Dordrecht i Arnhem. Najwięcej papierni powstalo najpierw w okręgu Veluwe, a później w okolicach zatoki Zuiderzee ${ }^{11}$. Ośrodki te leżą w niezbyt wielkim oddaleniu od miasta, gdzie oba omawiane dzieła zostały wydane. Jest więc bardzo prawdopodobne, że papier na którym je wydrukowa-

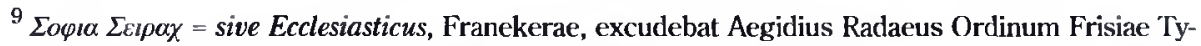
pographus, 1596; Sapientiam Iesu Sirach : seu Ecclesiasticum castigationes sive notae, [B.m.], [B.w.], 1596.

${ }^{10}$ Por. P. Dudziński, Alfabet heraldyczny. Warszawa 1997, s. 210-212.

${ }^{11}$ Encyklopedia wiedzy o ksiazzce, red. Aleksander Birkenmajer [i in.], Wroclaw 1971 (dalej cyt. EWOK), szp. 890.
} 
no pochodził $z$ kilku różnych czerpalni funkcjonujących na terenie Holandii. Jednakże trzeba również zaznaczyć, że papier ten mógl także pochodzić $z$ importu, np. z Niemiec, które graniczą z Niderlandami. Stamtąd też najprawdopodobniej pochodzi jeszcze jeden znak wodny odnaleziony w tych dwóch dziełach.

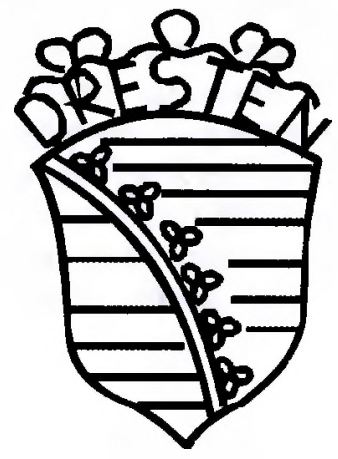

Rys. 5

Tzw. „mały wieniec” zawsze występował w znakach wodnych przedstawiających herb Saksonii. Najstarsze filigrany $z$ tym symbolem pochodzą $z$ drugiej połowy XV wieku $z$ Drezna (rys.5) oraz z miejscowości Weisseritz, gdzie długi czas utworzoną tam papiernię prowadziła rodzina Schaffhirt. Jednakże w związku $\mathrm{z}$ powstawaniem kolejnych czerpalni, znak wodny $\mathrm{z}$ herbem Saksonii zaczął pojawiać się na papierach $z$ innych warsztatów ${ }^{12}$. Tak więc można przypuszczać, że czerpalnia, $z$ której pochodzi badany papier, znajdowala się właśnie na terenie Saksonii. Również znak wodny przedstawiający skrzyżowane miecze (rys.4) może wskazywać na papiernię funkcjonującą w tym regionie, gdyż taki symbol był emblematem książąt Saksonii jako mieczników Cesarstwa Rzymskiego ${ }^{13}$. Nie jest więc wykluczone, że papiernia w której pojawil się taki znak wodny, stała na gruntach książęcych lub po prostu należała do któregoś $z$ władców tych ziem.
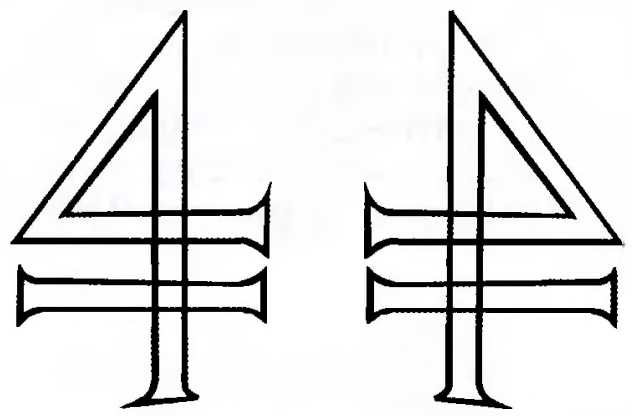

Rys. 6

${ }^{12}$ K. Briquet, Les Filigranes, t. 1, Amsterdam 1968, s. 99.

${ }^{13}$ P. Dudziński, dz. cyt., s. 123. 
Filigran odnaleziony na kartach drugiego tomu „Teologii dogmatycznej” wydanej w 1739 r. w Jenie i Lipsku ${ }^{14}$, występuje jedynie na dwóch ostatnich czystych kartach książki, tylko jeden raz. Trudno powiedzieć, który $\mathrm{z}$ układów symbolu jest poprawny, dlatego zaprezentowano obie możliwości (rys.6).

Znak ten jest identyczny $z$ gmerkiem używanym przez istniejącą w Polsce w XV-XVIII w. organizację zrzeszającą pełnoprawnych górników zwanych gwarkami. Korporacja ta eksploatowała kopalnie kruszcu głównie w Chęcinach i Olkuszu.Do tego stowarzyszenia oprócz mieszczan olkuskich należeli możni panowie, szlachta, dygnitarze a nawet królowie. $Z$ wydobywanego w Olkuszu srebra bito monety, na których umieszczano własne znaki ${ }^{15}[\mathrm{~m}$ in. prezentowany powyżej]. Być może papiernik, który byl producentem opisywanego papieru zetknąl się $z$ taką monetą i uwidoczniony na niej gmerk przyjął za filigran w swoim warsztacie?

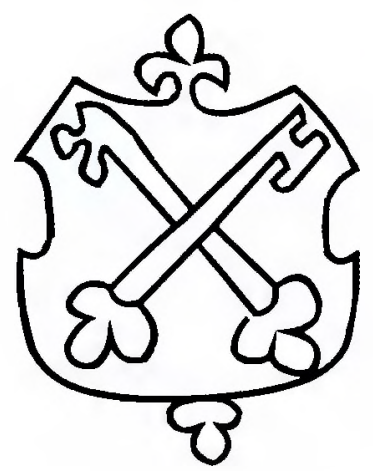

Rys. 7

Drugi z filigranów (rys.7) występujący na stronicach „Teologii” prezentuje skrzyżowane klucze. Motyw ten posiada w swoim herbie Ratyzbona, miasto w Bawarii. Jena i Lipsk, gdzie wydano ten tytuł, leżą w niedalekim sąsiedztwie zarówno od siebie, jak i od Ratyzbony. Jako filigran skrzyżowane klucze w ozdobnym kartuszu były wykorzystywane przez papiernie w ośrodku poznańskim od XVI wieku ${ }^{16}$. Nie jest wykluczone, że papier $z$ polskiej czerpalni trafił do niemieckiego drukarza.

${ }^{14} \mathrm{~J}$. Carpov, Theologiae revelatae dogmaticae: methodo scientificia adornatae, t. 2, Iena et Lipsiae, sumpt. Joh. Adam Melchior, 1739.

${ }^{15}$ Tamże, s. 223 i 226.

${ }^{16}$ K. Maleczyńska, dz. cyt., s. 141. 


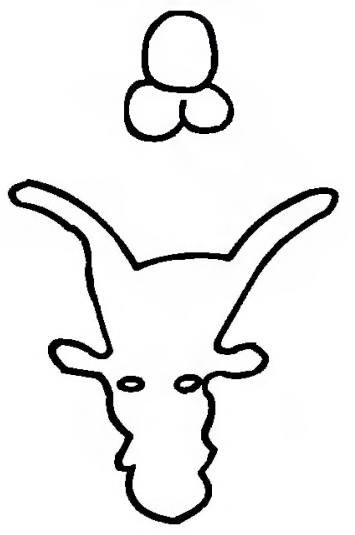

Rys. 8

Znak przedstawiony na rys. 8 występuje w dziele wydanym w Tybindze w roku $1613^{17}$. Głowa wolu to bardzo rozpowszechniony motyw na filigranach. Wól symbolizował Łukasza Ewangelistę, który był patronem cechu malarzy. Cech ten zrzeszał także papierników ${ }^{18}$. Natomiast trójliść koniczyny jest według założeń heraldycznych uznawany między innymi za symbol wiecznego trwania ${ }^{19}$. Być może papiernik, który użył takiego wariantu, uznal że jego produkt będzie wiecznie trwały i dlatego też przy symbolu własnego cechu umieścil znak trójlistnej koniczyny.

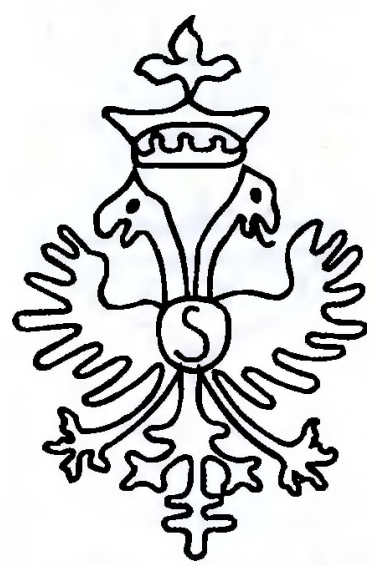

Rys. 9

${ }^{17}$ T. Wegelin, Vera \& Authentica relatio de Discursu theologico inter sereniss. et illustrissimos principes ac Dominos, Dn. Georgium Fridericum, marchionem Badensem ... et Dn. Franciscum Ducem Lotharingiae... : opposita falsis et fictiis relationibus, passim stylo famaq [ue] de hoc negotio temere leviterq [ue] sparsis accessit ludicum: de novo Jesuitarum contra omnes haereses Amuleto..., Tubingae, typ. Theodorici Werlini, 1613.

${ }^{18}$ B. Szyndler, I ksiązi majq swojq̨ historię, Warszawa 1982, s. 47.

${ }^{19}$ P. Dudziński, dz. cyt., s. 95. 
Dwuglowy orzeł (rys. 9) nawiązuje do głowy Janusa, reprezentującego sily stwórcze, wszechwiedzę. Symbol wykorzystywany jako orzeł cesarski w cesarstwie niemieckim, w Austro-Węgrzech oraz Cesarstwie Rosyjskim ${ }^{20}$. Korona na glowie orla, wprawdzie mocno uproszczona, jednakże pozwala według zasad heraldycznych dopatrywać się w jej kształcie książęcej korony niemieckiej ${ }^{21}$. Litera „S" na piersiach orła mogłaby sugerować godło Prus, jednakże orzeł $w$ herbie Prus był przedstawiany $z$ jedna głową 22 . Filigran $z$ orłem dwugłowym posiadała papiernia w Szkle, założona przez typografa lwowskiego Antoniego Pillera w roku $1772^{23}$. Lecz papier, na którym widnieje opisywany znak wodny jest starszy o przeszło 150 lat, więc nie może pochodzić $\mathrm{z}$ wyżej wspomnianej papierni.

Badany filigran występuje w dwóch książkach będących zapisem przebiegu rozpraw teologicznych odbytych w Ratyzbonie w roku 1601 . Dotyczyly one rozważań nad doktrynami katolickimi. Zostały wydane drukiem w Monachium w 1602 roku $^{24}$. Miasto to leży na terenie Bawarii, gdzie znajdowało się najwięcej papierni w Niemczech. $Z$ dużym więc prawdopodobieństwem można stwierdzić, że papiernia, $z$ której pochodzi badany papier, znajdowała się właśnie na terenie Bawarii; korona zaś na głowach orła może świadczyć o tym, iż papiernia ta mogła należeć lub stać na gruntach któregoś $\mathrm{z}$ książąt bawarskich.

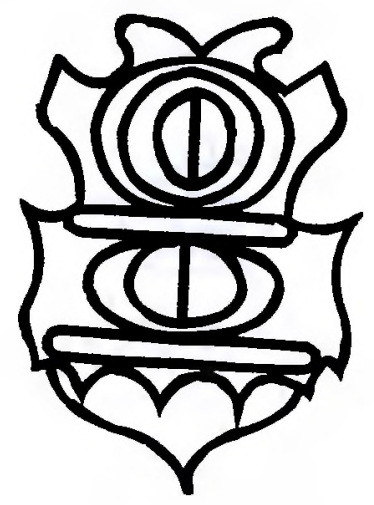

Rys. 10

Na kartach ratyzbońskich rozpraw teologicznych widnieje jeszcze drugi znak wodny (rys. 10). Według opinii Briqueta, taki znak wodny pojawial się przez bardzo długi okres czasu [od roku 1492 aż po wiek XVII]. Dopatrywano się

${ }^{20}$ W. Kopaliński, Stownik symboli, wyd. 2, Warszawa 1991, s. 287.

${ }^{21}$ P. Dudziński, dz. cyt., s. 22.

${ }^{22}$ J. Siniarska-Czaplicka, Katalog filigranów papierni polskich 1500-1800, Łódź 1983, s. 5.

${ }^{23}$ Tamże, s. 5.

${ }^{24}$ Actorum Colloqui Ratisbonensis de norma doctrinae Catholocae, et controversianum religionis Iudice, edit. secunda, Monachii, ex typogr. Nicolai Henrici, 1602; A. Tanner, Relatio compendiaria de inicio processu, et fine Coloquii Ratisbonensis, edit. secunda, Monachii, ex typogr. Nicolai Henrici, 1602. 
w nim herbu Pötschnera, patrycjuszowskiej rodziny $z$ Monachium. Papier $z$ tym filigranem rozprzestrzenił się na całym terenie obecnej Bawarii; przeniknął także na południe do Tyrolu w Austrii oraz na północ do Brandenburgii i Kassel ${ }^{25}$. Ponieważ oba dzieła, w których znajdujemy opisywany filigran, zostały wydane w Monachium, bardzo jest więc prawdopodobne, że papier użyty do druku pochodzil $\mathrm{z}$ wytwórni znajdującej się na terenie samej stolicy Bawarii lub w jej okolicach.

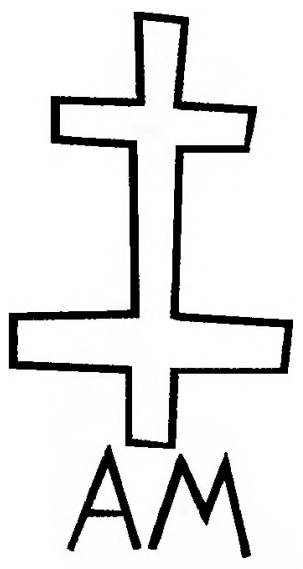

Rys. 11

Filigran na rys.11 charakteryzuje bardzo prosty ksztalt podwójnego krzyża. Podobny krzyż występuje w godle zakonu Świętego Ducha de Saxa. Taki filigran miała między innymi papiernia w Prądniku Czerwonym ${ }^{26}$. Jednakże krzyż herbowy tego zakonu mial rozdwojone końce ${ }^{27}$, a znak wodny $z$ badanego papieru ma wszystkie końce proste. Podobny w kształcie jest także krzyż lotaryński, godło Lotaryngii. Wprowadził go książę Rene Andegaweński, który umieszczał go jako swój herb na pieczęciach i monetach. Rozpowszechnienie tego znaku datuje się na rok 1471, kiedy to krzyż w takiej formie pojawił się na proporcach lotaryńczyków w bitwie pod Nancy ${ }^{28}$.

Książka, z której pochodzi omawiany filigran, została wydana w roku 1614 w Strasburgu ${ }^{29}$. Miasto to leży w niewielkiej odległości od regionu Lotaryngii. Jest prawdopodobne, że na tym terenie istniała papiernia używająca jako znaku wodnego właśnie symbolu Lotaryngii. Stąd też papier $z$ tego warsztatu mógl latwo trafić do drukarni w Strasburgu. Dlatego chyba bardziej prawdopodobne jest, że filigran występujący na tym papierze jest krzyżem lotaryńskim a nie

\footnotetext{
${ }^{25}$ K. Briquet, Les Filigranes, t. 1, s. 160.

${ }^{26}$ K. Maleczyńska, dz. cyt., s. 143.

${ }^{27}$ P. Dudziński, dz. cyt. s. 102.

${ }^{28}$ Tamże, s. 104 .

${ }^{29}$ Ch. Matthiae, M. Bregetzer, Disputatio inauguralis de norma et Iudice controversiarum theologicarum, Argentorati, typ. Joachimi Pedani, 1614.
} 
godłem zakonu duchaków, litery zaś umieszczone pod krzyżem mogą być inicjałami samego papiernika bądź właściciela warsztatu lub gruntu, na którym papiernia się znajdowała.

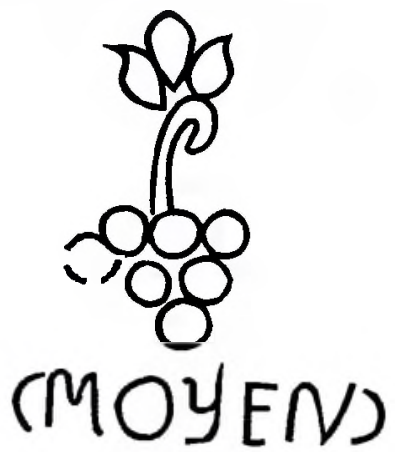

Rys. 12

Filigran (rys. 12) znajdujący się na kartach dzieła pt. La religion chretienne meditee... wydanego w roku $1736 \mathrm{w}$ Paryż ${ }^{30}$. Moyen to miasto we Francji w rejonie Lotaryngii ${ }^{31}$. Wizerunek winogrona może nawiazzywać do tradycji francuskich zwiazanych $z$ wyrobem win. Może papiernik posiadał również winnicę i wykorzystal ten symbol jako znak wodny na swoim papierze?

Dla oznaczenia papieru wprowadzono znaki literowe nazywane filigranami pomocniczymi. Najczęściej były to inicjały wlaścicieli gruntów, na których znajdowała się dana czerpalnia lub inicjały samego papiernika. Czasem litery te nawiazzywaly do nazwy miejscowości, w której istniała papiernia ${ }^{32}$.

Wśród znaków wodnych odnalezionych na kartach starodruków biblioteki WSD w Rzeszowie, znalazły się trzy filigrany literowe.

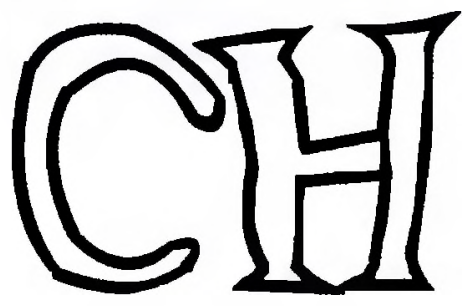

Rys. 13

Filigran (rys.13) zdjęty z książki pt. Dzieje i prawa Kościoła polskiego ${ }^{33}$. Tytuł wydany w największej drukarni zakonu pijarów w Warszawie. Trudno powie-

${ }^{30}$ Paris, [B.w.], 1736 .

${ }^{31}$ Zob. Andrees Allgemeiner Handatlas, 4. völ I. neubearbeit. u. Vermehrte Aufl., hrsg. A. Scobel, Bielefeld u. Leipzig 1900, k. 77-78.

${ }^{32}$ A. Wawrzeńczak, Znaki wodne, ,Spotkania z Zabytkami”, 3:1983, s. 35.

${ }^{33}$ T. Ostrowski, Dzieje y prawa Kościoła polskiego, t. 2, Warszawa 1793. 
dzieć skąd pozyskiwano papier na potrzeby tej oficyny. Mógł on bowiem pochodzić zarówno $z$ krajowych jak i zagranicznych czerpalni. Odnalezione litery można interpretować różnorako. Może to być np. skrót od lacińskiego słowa „charta”, co znaczy: papier, pismo, dokument ${ }^{34}$. Mogą to być także pierwsze litery miejscowości, w której znajdowała się papiernia, gdzie ten papier zostal wyprodukowany. [Np. Chelst - tam istniala papiernia od 1601 roku. Miejscowość ta należala do $t z w$. ośrodka wieleńskiego ${ }^{35}$. Być może są to początkowe litery imienia np. Christophorus [Krzysztof], osoby, która w jakiś sposób była zaangażowana w wyrób tego papieru. A także mogą to być inicjały właściciela gruntu, na którym stała czerpalnia lub samego papiernika.

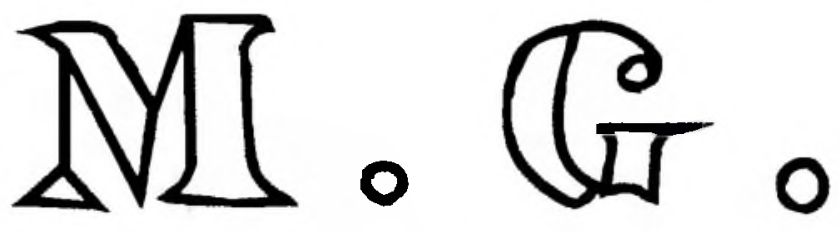

Rys. 14

Znak wodny na rys. 14 odnaleziony został na tylnej wyklejce dzieła pt. $K a$ zania y nauki wydanego w roku $1788 \mathrm{w}$ Warszawie ${ }^{36}$. Sądząc po układzie liter są to najprawdopodobniej inicjały imienia i nazwiska. Trudno orzec, do kogo mogly należeć. Niemniej w tym okresie działal Michał Gröll (1721-1798), który uważany jest za najwybitniejszego warszawskiego drukarza, księgarza, wydawcę i nakładcę w drugiej połowie XVIII wieku. Mial on zapewnione dostawy najlepszych gatunków papieru ${ }^{37}$. Nie jest wykluczone, że mógł otrzymywać papier $z$ wlasnym inicjalem. Wiele prac wydawanych $w$ jego oficynie było nielegalnie przedrukowywanych. Gröll, aby chronić swoje wydawnictwa przed takimi praktykami protestowal w licznych odezwach oraz wciąż zabiegał o różne przywileje nakładowe $^{38}$. Być może właśnie papier $z$ wlasnym inicjałem mial być również takim zabezpieczeniem własnościowym.

${ }^{34}$ Zob. A. Jougan, Stownik kościelny lacińsko-polski, wyd. 4, Warszawa 1992, s. 103.

${ }^{35}$ EWOK, szp. 1805.

${ }^{36}$ Kazania y nauki: czyli wyktad świętych Ewangelii na wszystkie niedziele y uroczystości tajemnic boskich w roku catym przepisanych sposobem $w$ homiliach dawnych Oyców Świętych używanym, Warszawa, [B.w.], 1788.

${ }^{37}$ EWOK, szp. 883-884.

${ }^{38}$ EWOK, szp. 885. 


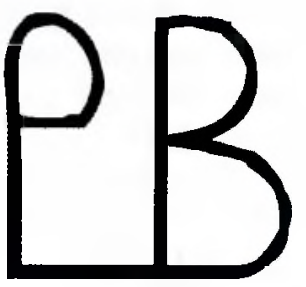

Rys. 15

Filigran $z$ rys. 15 występuje na kartach trzytomowego dzieła Gabriela Buceliniego Germania Topo-Chrono-Stemmato-Graphica Sacra et Profana z roku 1655. Wydane zostało przez nakładcę z Ulm, a wydrukowane w Augsburgu, gdzie już od XV wieku działała papiernia ${ }^{39}$. Jest więc bardzo prawdopodobne, że papier na którym wydano tę księgę pochodził właśnie $z$ tej czerpalni. Litery występujące w tym znaku wodnym to również najprawdopodobniej inicjały papiernika lub osoby związanej w jakiś sposób $z$ domniemaną papiernią.

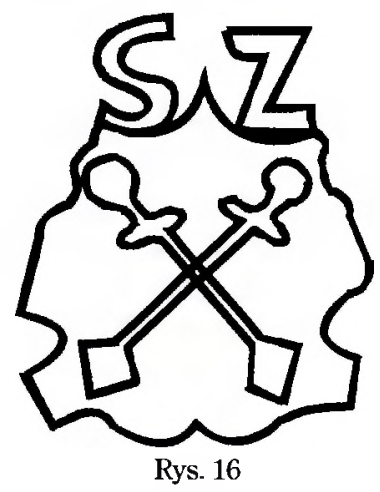

Znak wodny $\mathrm{z}$ rys. 16 odnaleziony został $\mathrm{w}$ dziele $\mathrm{z}$ roku $1613^{40}$. Wydawca pochodził $\mathrm{z}$ Monachium. Natomiast miejscem druku było miasto Ingolstadt. Trudno powiedzieć gdzie wyprodukowano papier, $z$ którego zostal odrysowany powyższy filigran. Podobne skrzyżowane miecze występowały w herbie królów Bawarii ${ }^{41}$. Nie jest to identyczny układ elementów, ale należy pamiętać, że w przypadku znaków wodnych wykorzystywane symbole mogły ulegać modyfikacji. Jednakże zarówno Monachium jak i Ingolstadt leżą na terenie Bawarii. W okresie do 1600 roku w Niemczech istnialo około 218 papierni, $z$ czego ponad 50 miało swoją lokalizację właśnie w Bawarii ${ }^{42}$.

${ }^{39}$ EWOK, szp. 1619.

${ }^{40}$ G. Vazquez, Paraphrasis et compendiaria explicatio ad nonnullas Pauli Epistolas, Inglostadii, Ex Typographeo Andreae Angermarii : Monacensis, Ioannis Hertstroi, 1613.

${ }^{41}$ Por. International Civic Heraldry [online]: http://www.ngw.nl/int/dld/bayern.htm [dostęp: 21 styczeń 20081.

${ }^{42}$ EWOK, szp. 1619. 


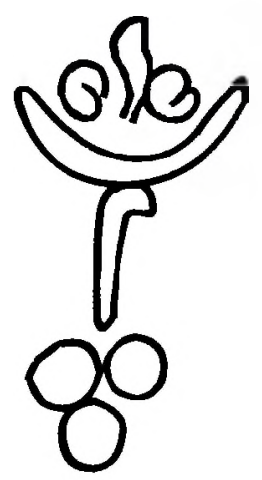

Rys. 17

Kolejny filigran (rys. 17) zawierający w swoim wizerunku winogrona, odnaleziony zostal na kartach „Katechizmu historycznego” wydanego w Paryżu w roku $1768^{43}$. Być może papier, na którym odbito ten znak wodny pochodził $z$ tej samej czerpalni gdzie wyprodukowano arkusze, na których wydrukowano ksiązkę już wcześniej opisaną również wydaną w Paryżu w roku 1763. Jednakże w przypadku filigranu przedstawionego wcześniej obok rysunku winogrona została podana nazwa miejscowości - Moyen. Może, więc jakaś inna papiernia wzorując się na czerpalni $z$ Moyen użyła w swoim znaku wodnym takiego samego symbolu.

\section{(AOLA)}

Rys. 18

Drugi znak wodny (rys. 18) występujący na kartach „Katechizmu” zawiera nazwę miejscową. Caolas to miejscowość w Szkocji. Jednakże może to być także nazwisko lub jakiś skrót znany jedynie osobie, która go stworzyła.

\footnotetext{
${ }^{43}$ M. Fleuty, Catechisme Historique : contenant en abrege l Historie Sainte \& la Doctrine Chretienne, Paris, chez Herissant Fils Libraire, 1768.
}

Z badań nad książką i księgozbiorami historycznymi, 3:2009 


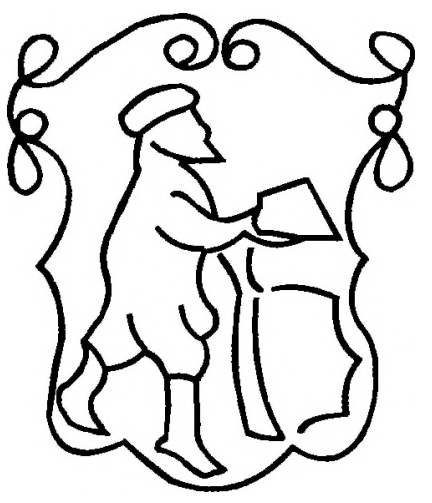

Rys. 19

Przepiękny filigran $z$ rys. 19 odnaleziony zostal na kartach „Biblii Świętej” wydanej w roku $1693 \mathrm{w}$ Bambergu ${ }^{44}$, mieście leżącym w Bawarii gdzie, jak już wspomniano wcześniej, zlokalizowane bylo ponad 25\% wybudowanych do 1600 roku czerpalni niemieckich. Być może przedstawia on papiernika podczas pracy, a bardzo często jako znak wodny przyjmowano symbole zwiazane właśnie $\mathrm{z}$ codzienną pracą warsztatów papierniczych ${ }^{45}$. Nie jest więc wykluczone, że papier na którym wytloczono tę Biblię pochodził z bawarskiej papierni, która mogła się znajdować również na terenie samego Bambergu.

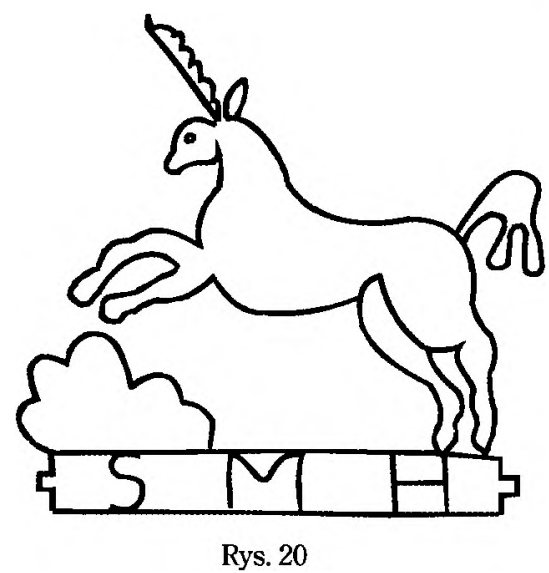

Drugi znak wodny (rys. 20), odnaleziony w tym samym dziele, pojawia się tylko jeden raz na ostatniej czystej karcie tzw. przybyszowej. Bardzo często filigrany przyjmowały kształty różnych zwierząt nie tylko realnych, ale i zupełnie fantastycznych. Jednym $z$ nich, pojawiającym się nie rzadko byla wlaśnie po-

\footnotetext{
${ }^{44}$ Biblia Sacra vulgate editionis Sixti V, Bambergae, sumpt. Wolfgangi Mauritii Endteri, 1693.

${ }^{45}$ K. Maleczyńska, dz. cyt., s. 132.
} 
stać jednorożca ${ }^{46}$. W heraldyce najczęściej wyobrażany był w skoku ${ }^{47}$. Trudno stwierdzić, co oznaczają litery umieszczone pod rysunkiem. Prawdopodobnie jest to skrót nazwy jakiegoś stowarzyszenia lub towarzystwa zarządzającego czerpalnią wykorzystującą ten znak wodny. Litera „S” w języku łacińskim jest stosowana niekiedy właśnie jako skrót od słowa societas [towarzystwo, stowarzyszenie zakonne męskie]. Być może była to papiernia zakonna.

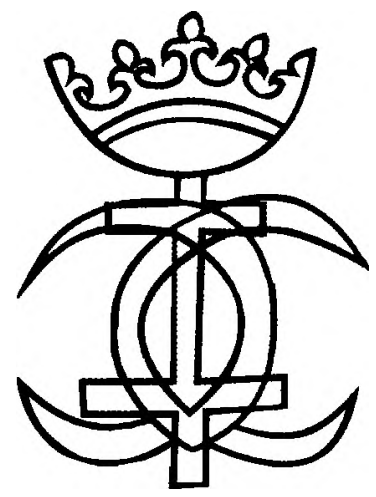

Rys. 21

Filigran przedstawiony na rys. 21 pochodzi $z$ książki pt. Vita Francisci Borgiae wydanej w roku $1603 \mathrm{w}$ Moguncij ${ }^{48}$. Znak ten przedstawia insygnia Karola III, księcia Lotaryngii i jego żony Klaudii Francuskiej. Według badań Karola Briqueta po raz pierwszy tego filigranu użyto w roku 1578 . $Z$ czasem stal się on bardzo popularny $\mathrm{w}$ papierniach lotaryńskich. Briquet sugeruje równiez, że opisywany znak wodny może pochodzić $z$ konkretnej papierni założonej w roku 1580 przez pana Auberta w miejscowości Arches ${ }^{49}$. Miasto, gdzie wydano omawiana pracę, leży w niewielkim oddaleniu od terenów Lotaryngii. Jest wiec bardzo prawdopodobne, że papier wytwarzany we francuskiej papierni trafił do niemieckiego drukarza.

Przedstawione tu filigrany to jedynie wybór spośród odnalezionych na kartach starych druków przechowywanych w Bibliotece Wyższego Seminarium Duchownego w Rzeszowie. Należy zaznaczyć, że rozpoznanie odnalezionych znaków wodnych jest w wielu przypadkach hipotetyczne. Niemożność dotarcia do wielu materiałów, które mogłyby w większym stopniu pomóc w identyfikacji opisywanych filigranów, nie pozwala na dokładne wskazanie konkretnej papierni, $\mathrm{z}$ której pochodził dany znak wodny. Również wiele $\mathrm{z}$ odnalezionych filigranów

\footnotetext{
${ }^{46}$ Tamże, s. 133.

${ }^{47}$ Kopaliński W., Stownik symboli..., s. 125.

${ }^{48}$ P. de Ribadeneyra, Vita Francisci Borgiae Tertii Societatis Jesu Generalis, Moguntiae, excudebat Balthasar Lippius, 1603.

${ }^{49}$ K. Briquet, Les Filigranes, t. 2, s. 493.
} 
nie udało się skopiować ze względu na zły stan techniczny papieru lub odbicie ich w miejscu niedostępnym, np. na złączu kart. Niemniej badania przeprowadzone właśnie na tym konkretnym zbiorze, pozwalają na poszerzenie wiedzy na temat znaków wodnych zachowanych na drukach przechowywanych w polskich bibliotekach kościelnych. 